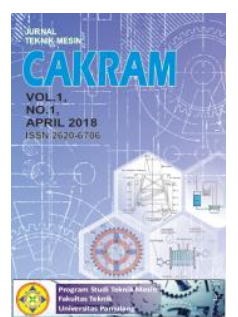

\title{
KELARUTAN MINERAL IKUTAN KASITERIT DALAM ASAM KLORIDA ENCER (HCl 10 \%) MENGGUNAKAN REAKTOR YANG DILENGKAPI PENGADUK
}

\author{
Latifa Hanum Lalasari \\ Program Studi Teknik Mesin, Universitas Pamulang, Jl. Surya Kencana No.1, Tangerang Selatan, Indonesia \\ E-mail : latifa.hanum@gmail.com \\ Masuk : 2 September 2020 \\ Direvisi : 12 September 2020 \\ Disetujui : 28 September 2020
}

\begin{abstract}
Abstrak: Telah dilakukan penelitian kelarutan mineral ikutan kasiterit $\left(\mathrm{SnO}_{2}\right)$ dalam larutan asam klorida $(\mathrm{HCl})$ encer menggunakan reaktor yang dilengkapi pengaduk. Tujuan penelitian adalah melakukan investigasi dalam upaya memperoleh kondisi proses yang optimum dan efisien, khususnya temperature dan waktu proses pelindian untuk menghasilkan kasiterit dengan kemurnian tinggi. Proses yang dilakukan adalah hidrometalurgi dengan melakukan proses pelindian mineral kasiterit dalam larutan $\mathrm{HCl} 10 \%$ (encer) pada kondisi tekanan atmosferik dan variasi temperatur $35^{\circ} \mathrm{C}, 50^{\circ} \mathrm{C}, 70^{\circ} \mathrm{C}, 90^{\circ} \mathrm{C}, 110^{\circ} \mathrm{C}$; waktu proses $1,2,3,4,5$, dan 6 jam. Proses pelindian menggunakan reaktor yang dilengkapi pengaduk dengan pengadukkan $300 \mathrm{rpm}$. Hasil penelitian menunjukkan larutan asam klorida $(\mathrm{HCl})$ 10\% mampu melarutkan mineral ikutan dari kasiterit diantaranya: besi, lantanum, cerium, titanium yang merupakan pengotor dengan jumlah besar dalam kasiterit. Kemurnian kasiterit yang diperoleh dari hasil pelindian menggunakan larutan $\mathrm{HCl} 10 \%$ (encer) adalah sebesar $82-83 \% \mathrm{SnO}_{2}$ pada temperatur $110{ }^{\circ} \mathrm{C}$ selama 2 jam.
\end{abstract}

Kata kunci: kasiterit, mineral ikutan, asam klorida, reaktor berpengaduk, pelindian

Abstract: Research on the solubility of associated minerals from cassiterite $\left(\mathrm{SnO}_{2}\right)$ in aqueous hydrochloric acid $(\mathrm{HCl})$ solution has been carried out using a reactor equipped with a stirrer. The research objective was to investigate in an effort to obtain optimum and efficient leaching process conditions, especially temperature and time to produce high purity cassiterite. The process was hydrometallurgical by leaching cassiterite in a $10 \%$ (dilute) $\mathrm{HCl}$ solution under conditions of atmospheric pressure and temperature variations of $35{ }^{\circ} \mathrm{C}, 50{ }^{\circ} \mathrm{C}, 70{ }^{\circ} \mathrm{C}, 90{ }^{\circ} \mathrm{C}, 110{ }^{\circ} \mathrm{C}$; and leaching times of $1,2,3,4,5$, and 6 hours. The leaching process used a reactor equipped with a stirrer at $300 \mathrm{rpm}$. The results showed that a $10 \%$ solution of hydrochloric acid $(\mathrm{HCl})$ was able to dissolve the trace minerals of cassiterite including: iron, lanthanum, cerium, titanium which were large amounts of impurities in cassiterite. The purity of cassiterite obtained from leaching using $10 \% \mathrm{HCl}$ solution (dilute) was $82-83 \% \mathrm{SnO}_{2}$ at $110{ }^{\circ} \mathrm{C}$ for 2 hours.

Keywords: cassiterite, associated minerals, hydrochloric acid, stirred reactor, leaching

\section{PENDAHULUAN}

Timah tidak ditemukan dalam unsur bebasnya di bumi, akan tetapi di peroleh dari senyawaannya. Timah pada saat ini diperoleh dari mineral cassiterite atau tin stone. Cassiterite merupakan mineral oksida dari timah $\mathrm{SnO}_{2}$. 
Timah terbentuk dari endapan primer batuan granit, serta sebagai endapan sekunder, yang di dalamnya terdiri dari endapan alluvial, elluvial, dan koluvium [1][2].

Timah (IV) Oksida $\left(\mathrm{SnO}_{2}\right)$ banyak dimanfaatkan untuk berbagai aplikasi karena stabil terhadap perlakuan panas, biaya pendeposisiannya yang relatif murah, dan sifat physicochemical yang baik. Titik leleh rendah dan adesi tegas untuk membersihkan permukaan besi, baja, tembaga, dan paduan tembaga memudahkan penggunaannya sebagai bahan pelapis tahan oksidasi [3][4].

Meski timah memiliki titik leleh reatif rendah $\left(232^{\circ} \mathrm{C}\right)$, peleburan harus dilakukan pada temperatur tinggi kira-kira $1300^{\circ} \mathrm{C}$ untuk memungkinkan slag dalam keadaan cair. Untuk mendapatkan lelehan Sn reduktor yang digunakan umumnya adalah karbon atau antrasit dan untuk menurunkan titik leleh slag perlu ditambah batu kapur. Dalam smelting ini sebagiannya terdapat pengotor, misalnya Fe ikut tereduksi dan berikatan dengan Sn dan terbawa bersama lelehan Sn (kadar sekitar 99,80\%). Karena slag peleburan pertama masih mengandung Sn relatif tinggi, maka perlu dilakukan pengolahan lebih lanjut untuk mendapatkan Sn kembali [1].

Fokus penelitian adalah memurnikan mineral kasiterit dimana kandungan timahnya banyak dimanfaatkan untuk aplikasi tin chemical. Mineral kasiterit mengandung mineral utama $\mathrm{SnO}_{2}$ dan mineral ikutan diantaranya kwarsa, ilmenit, monazit, rutil dan zircon [2][5]. Untuk memperoleh $\mathrm{SnO}_{2}$ dengan kemurnian tinggi maka kadar mineral-mineral ikutan tersebut harus diminimalisir. Pada kegiatan ini akan dilakukan percobaan pelarutan mineral kasiterit menggunakan asam lemah $\mathrm{HCl}$ dengan memvariasi waktu dan temperatur proses pelarutan.

Proses pemurnian kasiterit dari mineral ikutannya dapat dilakukan dengan proses pelindian (leaching). Namun untuk memperoleh kasiterit dengan kemurnian tinggi sesuai dengan spesifikasi yang diinginkan yaitu bisa diatas $90 \%$, terdapat banyak faktor yang mempengaruhinya, terutama pada proses pelarutan. Beberapa penelitian terdahulu dilakukakan diantaranya: pada proses leaching, kasiterit dipanggang pada suhu $90^{\circ} \mathrm{C}$ selama 120 menit dengan menggunakan pelarut $\mathrm{HCl} 25 \%$ untuk menghilangkan elemen pengotor utama, termasuk $\mathrm{Fe}, \mathrm{As}, \mathrm{S}, \mathrm{Pb}, \mathrm{dan}$ Sb. Dari hasil ditemukan bahwa $\mathrm{SnO}_{2}$ tidak bereaksi dan tidak larut dalam asam klorida [6]. Lalasari dkk (2020) menjelaskan $\mathrm{SnO}_{2}$ yang merupakan mineral utama kasiterit adalah hampir stabil dalam larutan asam kuat pekat dan yang terlarut diprediksi adalah mineral ikutan dari kasiterit [7]. Firdiyono et al (2018) melarutkan elemen Ce, Nd, Y dan La dari kasiterit menggunakan pelarut asam klorida, asama sulfat dan sodium hidroksida. Elemen tersebut adalah penyusun mineral monazit yang merupakan mineral ikutan dalam kasiterit [8]. Peng et al (2017) mencoba memisahkan mineral ikutan zirkon dari kasiterit dengan teknik flotasi menggunakan reagen sodium oleat [9]. Oyendika (2012) melakukan pelarutan mineral ikutan dari mineral kasiterit Nigeria menggunakan microwave [5].

Pada penelitian ini dilakukan investigasi yang sistematis untuk memperoleh kondisi proses yang optimum dan efisien. Variasi yang digunakan adalah waktu dan temperatur pelindian untuk menghilangkan elemen pengotor atau mineral ikutan dari mineral utamaya kasiterit $\left(\mathrm{SnO}_{2}\right)$ menggunakan asam $\mathrm{HCl}$ encer.

\section{METODOLOGI}

Bahan baku yang digunakan dalam penelitian ini adalah mineral kasiterit dari Kepulauan Bangka, Indonesia, larutan $\mathrm{HCl}$ 10\%, dan akuades. Larutan $\mathrm{HCl}$ berfungsi melarutkan mineral ikutan atau pengotor-pengotor pada mineral kasiterit sehingga diharapkan kandungan $\mathrm{SnO}_{2}$ memiliki kemurnian tinggi. Peralatan yang digunakan adalah neraca digital, labu ukur, corong penyaring dan reaktor labu leher tiga yang dilengkapi dengan pengaduk. Tahapan penelitian meliputi preparasi bahan dan proses pelindian. Dalam tahap preparasi : mineral kasiterit dihaluskan hingga -100 mesh kemudian dilakukan analisis X-ray Fluoresence (XRF) secara kuantitatif, untuk mengetahui komposisi kimia dari kasiterit. Sedangkan pelarut selektif $\mathrm{HCl}$ dipersiapan dari larutan $\mathrm{HCl} 37 \%$ (pekat) dilakukan pengenceran sampai diperoleh konsentrasi $\mathrm{HCl}$ 10\%. Tahap pelindian meliputi :1. Mengambil 10 gram mneral kasiterit kemudian dilarutkan menggunakan $\mathrm{HCl} 10 \%$ dalam wadah labu leher tiga; 2. Proses pelarutan dilakukan dengan variasi temperatur $35^{\circ} \mathrm{C}, 50^{\circ} \mathrm{C}, 70^{\circ} \mathrm{C}, 90^{\circ} \mathrm{C}, 110^{\circ} \mathrm{C}$ pada kecepatan pengadukkan $300 \mathrm{rpm}$. Proses juga dilakukan dengan pergantian variasi waktu 1 jam, 2 jam, 3 jam, 4 jam, 5 jam, dan 6 jam; 3. Kasiterit yang telah mengalami proses pelindian, disaring menggunakan kertas saring whatman No. 42 sehingga diperoleh filtrat pelindian dan residu kasiterit; 4.Residu dinetralkan menggunakan akuades kemudian residu diletakkan di atas nampan dan dikeringkan di dalam oven (muffle furnace) dan dipanaskan pada suhu $110^{\circ} \mathrm{C}$ selama 2 jam; 5. Setelah residu kering, kemudian dilakukan penimbangan dan dianalisis XRF. Hitung pengurangan berat residu dengan massa kasiterit awal. Diagram alir penelitian ditunjukkan pada Gambar 1. 


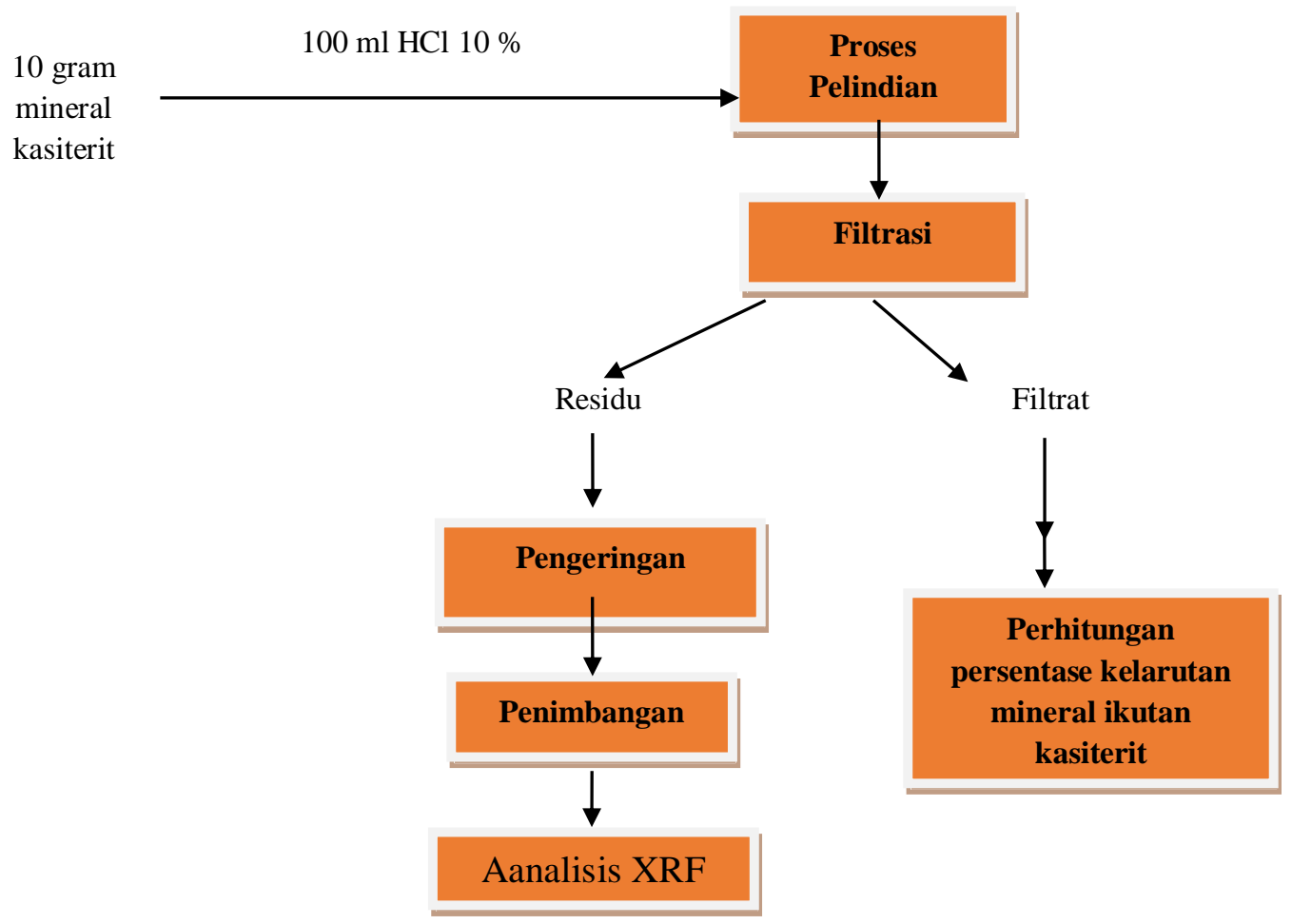

Gambar 1. Diagram Alir Penelitian

\section{HASIL DAN PEMBAHASAN}

\section{(a) Karakterisasi mineral kasiterit awal dengan XRF}

Analisis X-ray Fluoresence (XRF) secara kuantitatif, untuk mengetahui persentase komposisi komponen komponen yang terkandung dalam mineral kasiterit, Bangka - Indonesia. .Komposisi kimia mineral kasiterit ditunjukkan dalam Tabel 1.

Tabel 1. Komposisi kimia mineral kasiterit (dalam persen berat)

\begin{tabular}{|c|c|c|c|}
\hline Formula & Kadar (\%) & Formula & Kadar (\%) \\
\hline $\mathrm{Sn}$ & 57.82 & $\mathrm{Ti}$ & 1.45 \\
\hline $\mathrm{O}$ & 23.39 & $\mathrm{Ca}$ & 0.63 \\
\hline $\mathrm{La}$ & 3.43 & $\mathrm{~W}$ & 0.62 \\
\hline $\mathrm{Ce}$ & 3.37 & $\mathrm{Al}$ & 0.52 \\
\hline $\mathrm{Nd}$ & 2.18 & $\mathrm{Pr}$ & 0.51 \\
\hline $\mathrm{Fe}$ & 1.79 & $\mathrm{Si}$ & 0.45 \\
\hline $\mathrm{P}$ & 1.68 & $\mathrm{Cl}$ & 0.37 \\
\hline
\end{tabular}

Dari hasil analisis dengan menggunakan XRF yang ditunjukkan pada Tabel 1, diketahui bahwa pada kandungan tertinggi mineral kasiterit adalah Sn sebesar 57,72\% yang merupakan mineral utama dari kasiterit, sedangkan elemen ikutannya diantaranya 3,43\% lantanum (La), 3, 37\% cerium $(\mathrm{Ce}), 2,18 \%$ Neodymium $(\mathrm{Nd})$, $1,79 \%$ besi $(\mathrm{Fe}), 1,45 \%$ titanium $(\mathrm{Ti}), 0,63 \%$ kalsium $(\mathrm{Ca})$ dan lainnya. 
Latifa Hanum Lalasari, Kelarutan Mineral Ikutan Kasiterit Dalam Asam Klorida Encer ( $\mathrm{HCl} 10$ \%) Menggunakan Reaktor yang Dilengkapi Pengaduk

\section{(b) Pengaruh waktu terhadap kelarutan mineral ikutan kasiterit}

Untuk mempelajari pengaruh waktu proses terhadap kelarutan mineral ikutan kasiterit, dilakukan pelarutan 10 gram kasiterit dalam $100 \mathrm{ml}$ larutan $\mathrm{HCl} 10 \%$ selama 1, 2, 3, 4, 5, dan 6 jam dalam berbagai termperatur. Data penelitian dan pengolahaannya dapat ditunjukkan Tabel 2,3,4,5 dan 6 .

Tabel 2. Pengaruh waktu terhadap kelarutan mineral ikutan kasiterit pada temperatur $35{ }^{\circ} \mathrm{C}$

\begin{tabular}{|c|c|c|}
\hline Waktu (menit) & Massa padatan (gram) & Massa terlarut (\%) \\
\hline 60 & 9,86 & 1,4 \\
\hline 120 & 9,45 & 5,5 \\
\hline 180 & 9,48 & 5,2 \\
\hline 240 & 9,75 & 2,5 \\
\hline 300 & 9,55 & 4,5 \\
\hline 360 & 9,61 & 3,9 \\
\hline
\end{tabular}

Tabel 3. Pengaruh waktu terhadap kelarutan mineral ikutan kasiterit pada temperatur $50{ }^{\circ} \mathrm{C}$

\begin{tabular}{|c|c|c|}
\hline Waktu (menit) & Massa padatan (gram) & Massa terlarut (\%) \\
\hline 60 & 9,71 & 2,9 \\
\hline 120 & 9,51 & 4,9 \\
\hline 180 & 9,69 & 3,1 \\
\hline 240 & 9,74 & 2,6 \\
\hline 300 & 9,74 & 2,6 \\
\hline 360 & 9,51 & 4,9 \\
\hline
\end{tabular}

Tabel 4. Pengaruh waktu terhadap kelarutan mineral ikutan kasiterit pada temperature $7^{\circ} \mathrm{C}$

\begin{tabular}{|c|c|c|}
\hline Waktu (menit) & Massa padatan (gram) & Massa terlarut (\%) \\
\hline 60 & 9,79 & 2,1 \\
\hline 120 & 9,67 & 3,3 \\
\hline 180 & 9,68 & 3,2 \\
\hline 240 & 9,45 & 5,5 \\
\hline 300 & 9,77 & 2,3 \\
\hline 360 & 9,76 & 2,4 \\
\hline
\end{tabular}

Tabel 5. Pengaruh waktu terhadap kelarutan mineral ikutan kasiterit pada temperatur $90^{\circ} \mathrm{C}$

\begin{tabular}{|c|c|c|}
\hline Waktu (menit) & Massa padatan (gram) & Massa terlarut (\%) \\
\hline 60 & 9,72 & 2,8 \\
\hline 120 & 9,56 & 4,4 \\
\hline 180 & 9,58 & 4,2 \\
\hline 240 & 9,65 & 3,5 \\
\hline 300 & 9,57 & 4,3 \\
\hline 360 & 9,22 & 6,8 \\
\hline
\end{tabular}

Tabel 6. Pengaruh waktu terhadap kelarutan mineral ikutan kasiterit pada temperatur $110^{\circ} \mathrm{C}$

\begin{tabular}{|c|c|c|}
\hline Waktu (menit) & Massa padatan (gram) & Massa terlarut (\%) \\
\hline 60 & 9,33 & 6,7 \\
\hline 120 & 9,32 & 6,8 \\
\hline 180 & 9,55 & 4,5 \\
\hline 240 & 9,58 & 4,2 \\
\hline 300 & 9,51 & 4,9 \\
\hline 360 & 9,79 & 2,1 \\
\hline
\end{tabular}




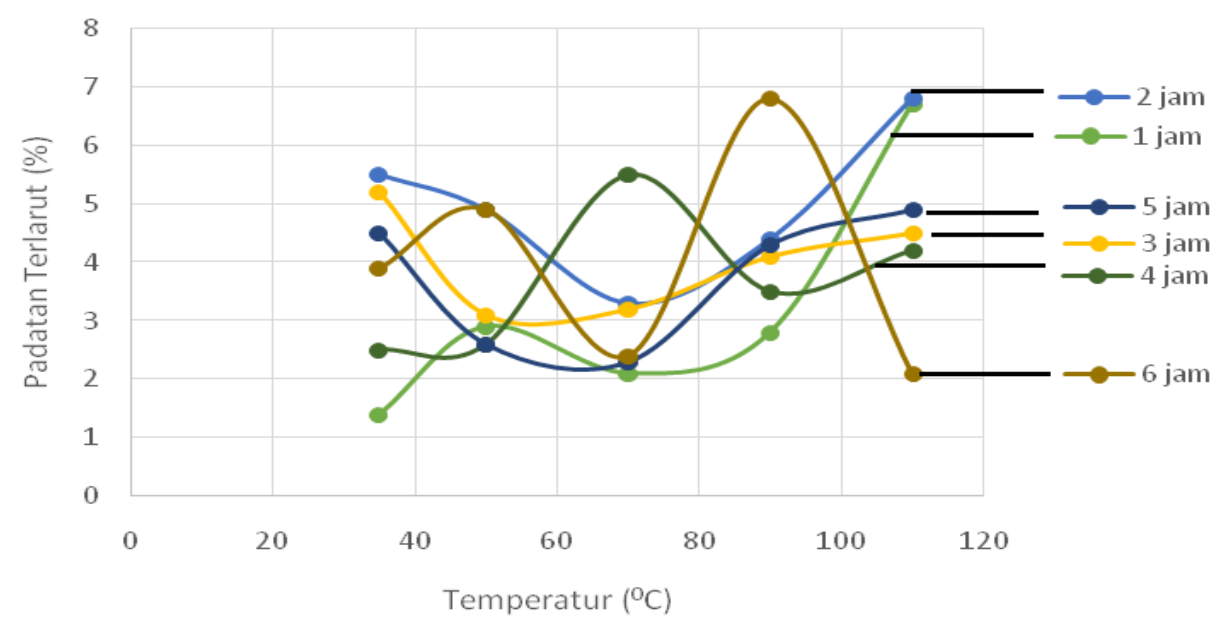

Gambar 2. Pengaruh waktu terhadap kelarutan mineral ikutan kasiterit pada berbagai temperatur

Gambar 2 merupakan pengaruh waktu terhadap kelarutan mineral ikutan kasiterit pada berbagai temperatur. Gambar 2 menunjukkan kelarutan mineral ikutan kasiterit pada berbagai waktu pelarutan tidak linier. Kelarutan mineral ikutan kasiterit maksimum terdapat di titik waktu 2 jam dengan presentase hasil 6,8\%. Sebelum itu, kelarutan kasiterit mengalami penurunan namun tidak signifikan. Kelarutan mineral ikutan kasiterit pada waktu 2 jam dapat dilihat pada Gambar 3.

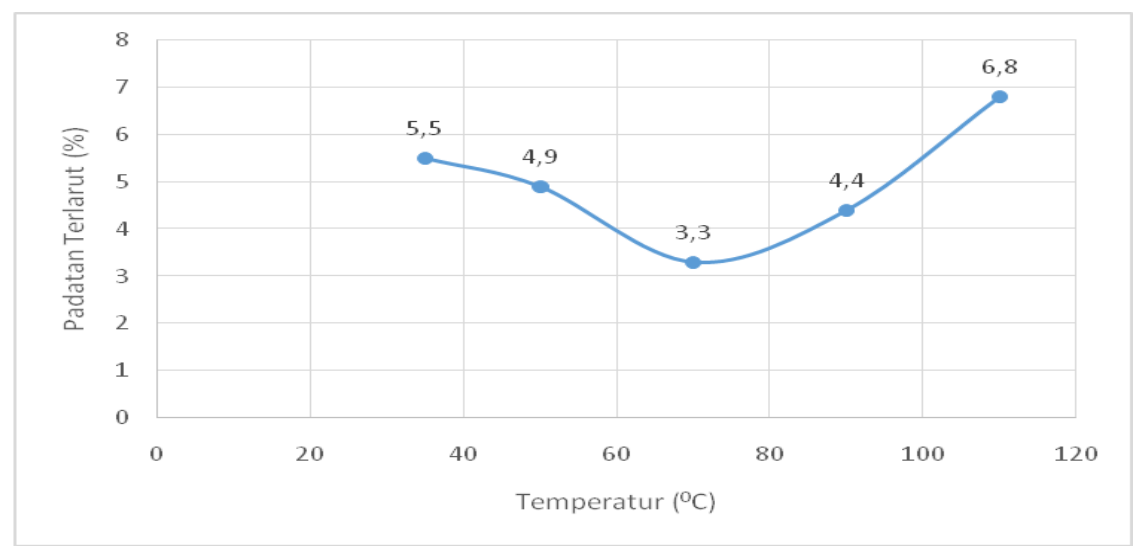

Gambar 3. Kelarutan mineral ikutan kasiterit pada waktu 2 jam

Hasil kelarutan mineral ikutan kasiteri pada waktu di atas 2 jam mengalami sedikit penurunan namun juga terjadi kenaikan setelah melewati titik minimum. Hal ini diakibatkan oleh penurunan elemen penyusun kasiterit, beberapa diantaranya mengalami oksidasi. Hal ini bisa terjadi mengingat terdapat banyak kandungan air berlebih selama proses pelindian sehingga oksigen terlarut semakin banyak pada kondisi atmosferik. Adanya interaksi oksigen dalam sistem dimungkinkan elemen ikutan kasiterit mengalami oksidasi sehingga ikut terpresipitasi kembali bersama mineral utamanya kasiterit $\left(\mathrm{SnO}_{2}\right)$. 


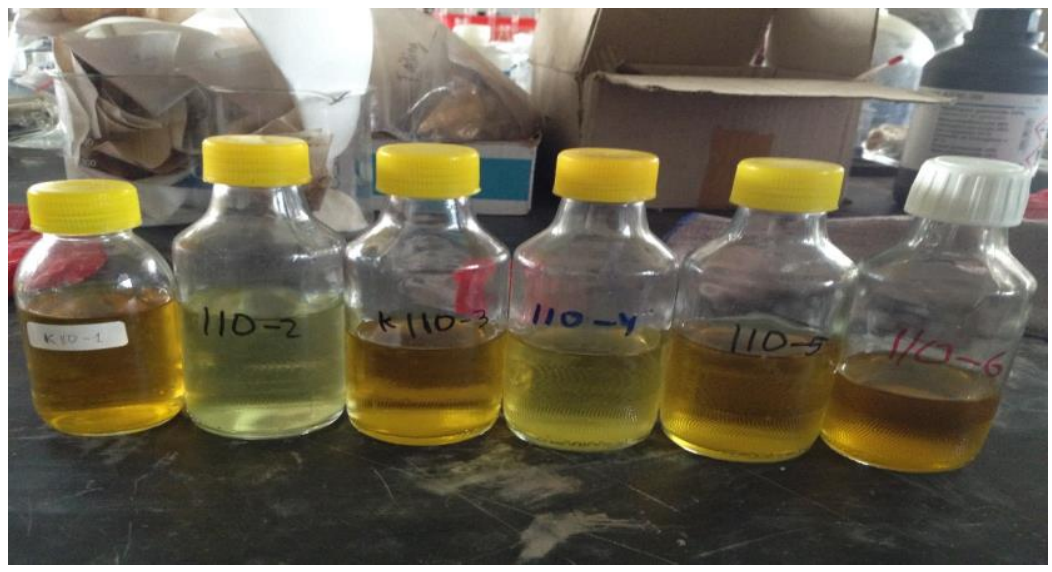

Gambar 4. Filtrat hasil pelindian pada temperatur $110^{\circ} \mathrm{C}$ berbagai waktu pelarutan

Pada Gambar 4 terlihat warna filtrat adalah hijau pekat.Mengacu pada penelitian Lalasari, et al [7][10] menjelaskan bahwa besi bersifat tidak stabil dalam larutan asam sehingga kelarutan besi lebih besar dibanding dengan titanium, silikon, dan timah. Warna hijau pekat mengindikasi banyaknya kandungan besi yang terlarut dalam larutan $\mathrm{HCl} 10 \%$. Timah bersifat stabil dalam larutan $\mathrm{HCl} \mathrm{10 \%} \mathrm{sehingga} \mathrm{tidak} \mathrm{mudah} \mathrm{larut.}$

\section{(c) Pengaruh temperatur terhadapap kelarutanmineral ikutan kasiterit}

Untuk mempelajari pengaruh temperatur proses terhadap kelarutan mineral ikutan kasiterit, dilakukan pelarutan 10 gram kasiterit dalam $100 \mathrm{ml}$ larutan $\mathrm{HCl} 10 \%$ pada temperatur $35^{\circ} \mathrm{C}, 50{ }^{\circ} \mathrm{C}, 70{ }^{\circ} \mathrm{C}, 90{ }^{\circ} \mathrm{C}$, dan $110{ }^{\circ} \mathrm{C}$ dalam berbagai waktu. Data penelitian dan pengolahaannya dapat ditunjukkan Tabel 7,8,9, 10, 11 dan 12.

Tabel 7. Pengaruh temperatur terhadap kelarutan mineral ikutan kasiterit pada pelarutan 1 jam

\begin{tabular}{|c|c|c|}
\hline Temperatur $\left({ }^{\circ} \mathbf{C}\right)$ & Massa padatan (gram) & Massa terlarut $(\%)$ \\
\hline 35 & 9,86 & 1,4 \\
\hline 50 & 9,71 & 2,9 \\
\hline 70 & 9,79 & 2,1 \\
\hline 90 & 9,72 & 2,8 \\
\hline 110 & 9,33 & 6,7 \\
\hline
\end{tabular}

Tabel 8. Pengaruh temperatur terhadap kelarutan mineral ikutan kasiterit pada pelarutan 2 jam

\begin{tabular}{|c|c|c|}
\hline Temperatur $\left({ }^{\circ} \mathbf{C}\right)$ & Massa padatan (gram) & Massa terlarut $(\%)$ \\
\hline 35 & 9,45 & 5,5 \\
\hline 50 & 9,51 & 4,9 \\
\hline 70 & 9,67 & 3,3 \\
\hline 90 & 9,56 & 4,4 \\
\hline 110 & 9,32 & 6,8 \\
\hline
\end{tabular}


Latifa Hanum Lalasari, Kelarutan Mineral Ikutan Kasiterit Dalam Asam Klorida Encer ( $\mathrm{HCl} 10$ \%) Menggunakan Reaktor yang Dilengkapi Pengaduk

Tabel 9. Pengaruh temperatur terhadap kelarutan mineral ikutan kasiterit pada pelarutan 3 jam

\begin{tabular}{|c|c|c|}
\hline Temperatur $\left({ }^{\mathbf{0}} \mathbf{C}\right)$ & Massa padatan (gram) & Massa terlarut (\%) \\
\hline 35 & 9,48 & 5,2 \\
\hline 50 & 9,69 & 3,1 \\
\hline 70 & 9,68 & 3,2 \\
\hline 90 & 9,58 & 4,2 \\
\hline 110 & 9,55 & 4,5 \\
\hline
\end{tabular}

Tabel 10. Pengaruh temperatur terhadap kelarutan mineral ikutan kasiterit pada pelarutan 4 jam

\begin{tabular}{|c|c|c|}
\hline Temperatur $\left({ }^{\mathbf{0}} \mathbf{C}\right)$ & Massa padatan (gram) & Massa terlarut (\%) \\
\hline 35 & 9,75 & 2,5 \\
\hline 50 & 9,74 & 2,6 \\
\hline 70 & 9,45 & 5,5 \\
\hline 90 & 9,65 & 3,5 \\
\hline 110 & 9,58 & 4,2 \\
\hline
\end{tabular}

Tabel 11. Pengaruh temperatur terhadap kelarutan mineral ikutan kasiterit pada pelarutan 5 jam

\begin{tabular}{|c|c|c|}
\hline Temperatur $\left({ }^{\mathbf{0}} \mathbf{C}\right)$ & Massa padatan (gram) & Massa terlarut (\%) \\
\hline 35 & 9,55 & 4,5 \\
\hline 50 & 9,74 & 2,6 \\
\hline 70 & 9,77 & 2,3 \\
\hline 90 & 9,57 & 4,3 \\
\hline 110 & 9,51 & 4,9 \\
\hline
\end{tabular}

Tabel 12. Pengaruh temperatur terhadap kelarutan mineral ikutan kasiterit pada pelarutan 6 jam

\begin{tabular}{|c|c|c|}
\hline Temperatur $\left({ }^{\mathbf{0}} \mathbf{C}\right)$ & Massa padatan (gram) & Massa terlarut (\%) \\
\hline 35 & 9,61 & 3,9 \\
\hline 50 & 9,51 & 4,9 \\
\hline 70 & 9,76 & 2,4 \\
\hline 90 & 9,22 & 7,8 \\
\hline 110 & 9,79 & 2,1 \\
\hline
\end{tabular}




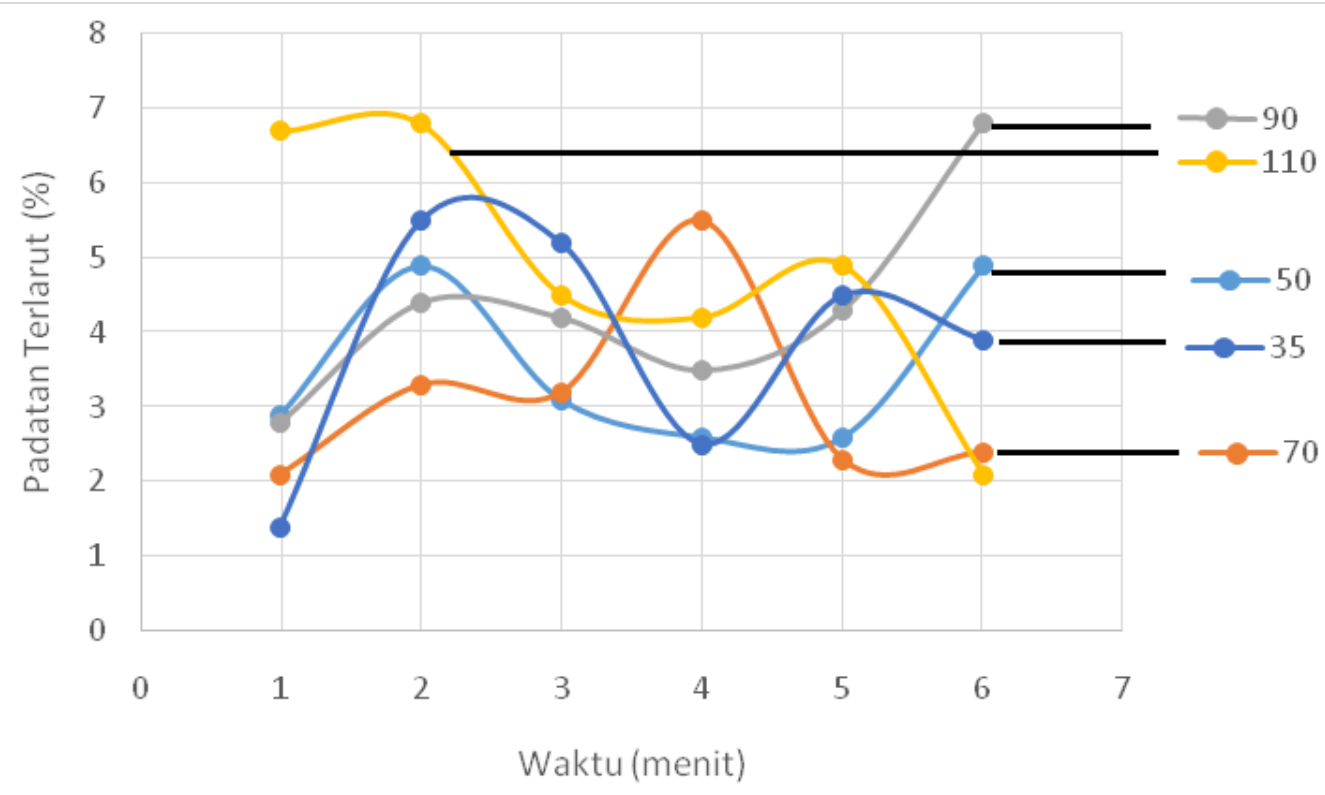

Gambar 5. Pengaruh temperatur terhadap kelarutan mineral ikutan kasiterit pada berbagai waktu proses pelindian

Gambar 5 menunjukkan pengaruh temperatur terhadap kelarutan mineral ikutan kasiterit. Pada gambar tersebut terlihat jumlah padatan terlarut paling banyak terdapat pada temperatur $110^{\circ} \mathrm{C}$ yaitu sebanyak $6,8 \%$. Untuk lebih jelasnya dapat dilihat pada Gambar 6.

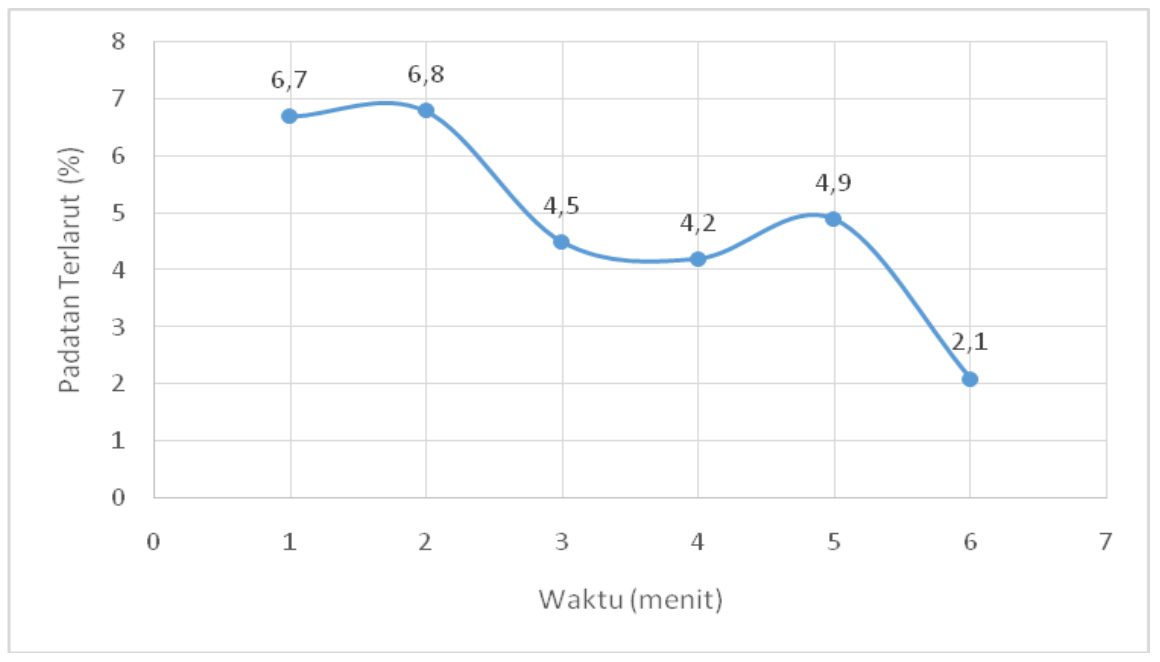

Gambar 6. Kelarutan mineral ikutan kasiterit pada temperatur $110^{\circ} \mathrm{C}$

Sama halnya dengan Gambar 3, hasil yang diperoleh tidak linier. Terdapat penurunan hasil setelah optimum 2 jam. Faktor yang sama pada Gambar 3 dapat terjadi. Hasil yang tidak linier dalam percobaan ini juga dapat diakibatkan oleh residu hasil proses pelindian meningkat jumlahnya karena elemen pengikut kasiterit teroksidasi dan terpresipitasi bersama mineral utamanya $\mathrm{SnO}_{2}$. Hasil akurat dapat diperoleh dari uji XRF. 


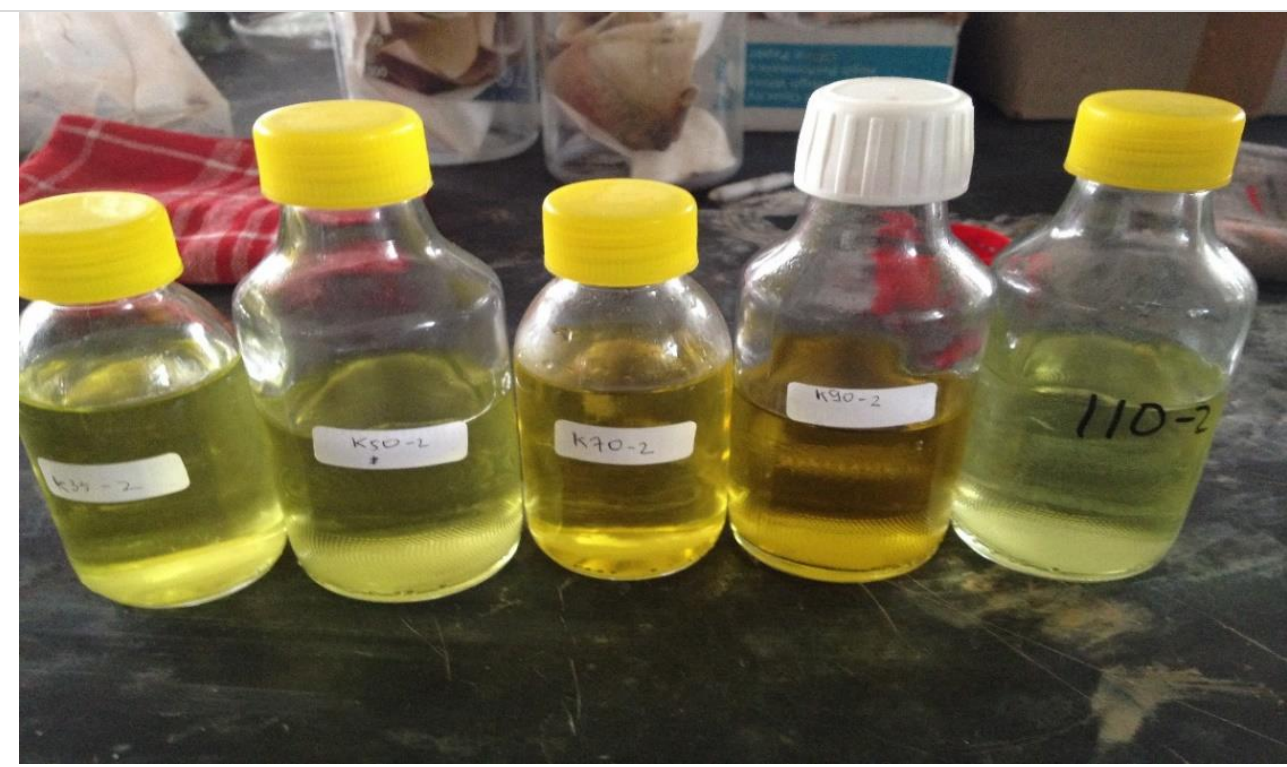

Gambar 7. Perubahan warna filtrat pada berbagai temperatur

Pada gambar 7 terlihat bahwa warna filtrat adalah hijau. Pada temperatur $70^{\circ} \mathrm{C}$ dan $90^{\circ} \mathrm{C}$, filtrat berwarna lebih pekat. Menurut Lalasari, et al .(2015) [10], kelarutan maksimum besi terjadi pada range $70-90^{\circ} \mathrm{C}$ yaitu diatas $90 \%$. Pada suhu lebih rendah dari $70^{\circ} \mathrm{C}$, elemen besi dari kasiterit tidak terlarut namun di atas $90^{\circ} \mathrm{C}$ kelarutan besi menurun karena efek oksidasi lanjut sehingga besi lebih stabil dalam oksidanya, sedangkan titanium dan silikon mulai terlarut tidak signifikan yaitu dibawah $1 \%$.

\section{(d) Karakterisasi residu hasil proses pelindian dengan XRF}

Untuk mengetahui kelarutan mineral ikutan kasiterit menggunakan larutan $\mathrm{HCl} 10 \%$ (encer) maka dilakukan karakterisasi XRF pada residu hasil proses pelindian yang ditunjukkan pada Tabel 13.

Tabel 13. Komposisi kimia residu hasil prose pelindian menggunakan larutan $\mathrm{HCl} 10 \%$ (dalam persen berat)

\begin{tabular}{|c|c|c|c|}
\hline \multirow{2}{*}{ Elemen } & \multicolumn{3}{|c|}{ Kadar (\%) } \\
\cline { 2 - 4 } & $\mathbf{3 5}^{\circ} \mathbf{C}(\mathbf{2}$ jam) & $\mathbf{1 1 0}^{\circ} \mathbf{C}(\mathbf{1}$ jam) & $\mathbf{1 1 0}^{\circ} \mathbf{C}(\mathbf{2}$ jam $)$ \\
\hline $\mathrm{Ti}$ & 1.22 & 1.26 & 1.38 \\
\hline $\mathrm{Si}$ & 0.38 & 0.39 & 0.27 \\
\hline $\mathrm{La}$ & 2.12 & 1.97 & 2.12 \\
\hline $\mathrm{Fe}$ & 1.22 & 1.12 & 1.18 \\
\hline $\mathrm{Ce}$ & 2.03 & 1.94 & 2.03 \\
\hline $\mathrm{Sn}$ & 64.72 & 65.54 & 66.14 \\
\hline
\end{tabular}

Apabila dibandingkan antara karakterisasi mineral kasiterit awal (Tabel 3) dan residu hasil proses pelindian (Tabel 13) terlihat bahwa larutan asam klorida 10\% mampu melarutkan mineral ikutan dari kasiterit. Dari Tabel 13 dapat dilihat bahwa pengotor seperti besi, lanthanum, cerium, titanium dan silika merupakan pengotor dengan jumlah besar dalam kasiterit. Setelah dilakukan proses leaching presentase timah dalam kasiterit meningkat. 
Kadar $\mathrm{Sn}$ sebesar 64-66\% dengan presentase $\mathrm{SnO}_{2}$ sebesar 82-83\%. Hasil yang didapat belum maksimum dikarenakan konsentrasi asam klorida yang digunakan sebagai pelarut selektif adalah rendah yaitu larutan $\mathrm{HCl} 10 \%$.

Uji XRF (Tabel 13) menunjukkan pelarutan pada temperatur $110^{\circ} \mathrm{C}$ mampu melarutkan pengotor dalam jumlah besar. Ditunjukkan dengan presentase pengotor pada Tabel 3 dengan kenaikan kadar Sn. Suhu $110^{\circ} \mathrm{C}$ merupakan suhu maksimum dalam percobaan ini. Suhu yang tinggi mampu meningkatkan jalannya reaksi kimia pada proses pelindian. Namun pada suhu $35^{\circ} \mathrm{C}$, kandungan $\mathrm{Sn}$ mengalami peningkatan. Suhu $35^{\circ} \mathrm{C}$ merupakan suhu minimum dalam percobaan, namun pada suhu ini asam klorida mampu melarutkan pengotor dalam jumlah besar.

\section{KESIMPULAN}

Kesimpulan yang didapatkan dari hasil penelitian ini adalah sebagai berikut: larutan asam klorida encer (HCl) 10\%) mampu melarutkan mineral ikutan (pengotor) dari kasiterit sekitar 40\%. Pengotor seperti besi, lantanum, cerium, titanium, silikon merupakan pengotor dengan jumlah besar dalam kasiterit. Setelah dilakukan proses leaching presentase timah dalam kasiterit meningkat. Kadar Sn sebesar 64-66\% dengan presentase $\mathrm{SnO}_{2}$ sebesar $82-83 \%$. Waktu optimal yang disarankan untuk menghilangkan mineral ikutan kasiterit menggunakan larutan $\mathrm{HCl}$ encer adalah 2 jam karena mampu melarutkan pengotor dan temperatur optimal yang disarakan adalah $110^{\circ} \mathrm{C}$. Pada temperatur ini diperoleh kelarutan maksimum pengotor terutama besi. Penelitian ini perlu dilanjutkan dengan melakukan perlakuan awal pada mineral kasiterit menggunakan aditif dan atau proses pirometalurgi. Proses perlakuaan awal dilakukan untuk meningkatkan kelarutan mineral ikutan dari kasiterit sebelum dilakukan proses pelindian (leaching) menggunakan larutan $\mathrm{HCl}$ encer.

\section{DAFTAR PUSTAKA}

[1] H Djamaluddin; Meinarni Thamrin; Alfajrin Achmad, "Potensi dan prospek peningkatan nilai tambah mineral logam di Indonesia (suatu kajian terhadap upaya konservasi mineral)," Pros. Has. Penelit. Fak. Tek., pp. 1-13, 2012.

[2] G. Onyedika, Z. Peng, and B. Li, "Mineralogical Characterization of Kuru Cassiterite Ore by SEM-EDS , XRD and ICP Techniques,” J. Miner. Mater. Charact. Eng., vol. 10, no. 9, pp. 855-863, 2011.

[3] M. Batzill and U. Diebold, “The surface and materials science of tin oxide,” vol. 79, pp. 47-154, 2005.

[4] A. Suharyanto and L. H. Lalasari, "POTENSI MINERAL KASITERIT INDONESIA SEBAGAI BAHAN BAKU PEMBUATAN SENYAWA KIMIA TIMAH ( TIN CHEMICAL ),” jurnal.umj.ac.id/index.php/semnastek, vol., no. November, pp. 1-6, 2016.

[5] G. Okwuch. ONYEDIKA, "MICROWAVE - ASSISTED HYDROMETALLURGICAL BENEFICIATION OF A CASSITERITE ORE IN KURU, NIGERIA,” Federal University of Technology, Owerri, 2012.

[6] Peter A. Wright, Extractive Metallurgy of Tin. Elsevier Scientific Publishing Company, 1982.

[7] L. H. Lalasari et al., "The dissolution of cassiterite Indonesia using hydrometallurgical process in the aerated reactor The Dissolution of Cassiterite Indonesia Using Hydrometallurgical Process in The Aerated Reactor," AIP Conf. Proc. 2232, vol. 040001, no. April, 2020.

[8] F. Firdiyono; et al., "Preliminary Study on the Dissolutions of Ce , Nd, Y and La from Mineral Cassiterite by Acid and Alkaline Leaching Preliminary Study on the Dissolutions of Ce , Nd, Y and La from Mineral Cassiterite by Acid and Alkaline Leaching," IOP Conf. Ser. Mater. Sci. Eng., vol. 333, no. 012040, pp. 1-8, 2018.

[9] H. Peng et al., "Study on the Effect of Fe 3 + on Zircon Flotation Separation from Cassiterite Using Sodium Oleate as Collector," Minerals, vol. 7, no. 108, pp. 1-18, 2017.

[10] L. H. Lalasari;, Y. D. R., A. Suharyanto, and F. Firdiyono, "Characterization and dissolution of CassiteriteIndonesia mineral in various concentrations of hydrochloric acid," Proceeding 2 nd Int. Conf. Mater. Metall. Technol. 2015 (ICOMMET 2015), pp. 375-379, 2015. 